\title{
Effect of Motivation, Training and Compensation on Employee Performance at PT. Wahyu Septyan Bengkulu
}

\section{Pengaruh Motivasi, Pelatihan dan Kompensasi terhadap Kinerja Karyawan pada PT. Wahyu Septyan Bengkulu}

\author{
Sandi Anugrah Hidayah 1); Siti Hanila2); Rina Trisna Yanti2) \\ 1)Study Program of Management, Faculty of Economic, Universitas Dehasen Bengkulu \\ ${ }^{2)}$ Department of Accountancy, Faculty of Economic, Universitas Dehasen Bengkulu \\ Email: 1) sandianugrah30@gmail.com; ${ }^{2)}$ st.hanila@unived.ac.id; ${ }^{2)}$ rinatrisnayanti@rocketmail.com;
}

How to Cite :

Hidayah, S. A., Hanila, S., Yanti, R. T. (2021). Effect of Motivation, Training and Compensation on Employee Performance at PT. Wahyu Septyan Bengkulu. EMAK: Jurnal Ekonomi Manajemen Akuntansi Dan Keuangan, 2(4). DOI: https://doi.org/10.53697/emak.v2i4

ARTICLE HISTORY

Received [12 Agust 2021]

Revised [25 Agust 2021]

Accepted [05 October 2021]

KEYWORDS

Motivation, Training, Compensation and Employee Performance

This is an open access article under the $C C-B Y$-SA license

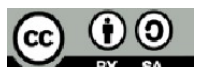

\section{ABSTRAK}

Penelitian ini bertujuan untuk mengetahui pengaruh motivasi, pelatihan dan kompensasi terhadap kinerja karyawan pada PT. Wahyu Septyan Bengkulu. Sampel dalam penelitian ini sebanyak 60 orang karyawan PT. Wahyu Septyan Bengkulu. Pengumpulan data menggunakan kuesioner dan metode analisis yang digunakan yaitu rankspearman dan uji t. Hasil dari analisis rank spearmanmenunjukan terdapat pengaruh signifikan motivasi (X1) terhadap kinerja karyawan (Y) dengan nilai rho $(\rho)$ hitung $=0,631$ dalam kriteria 0,60-0,799 (kuat), terdapat pengaruh signifikan pelatihan (X2) terhadap kinerja karyawan $(Y)$ dengan nilai rho $(\rho)$ hitung $=0,687$ dalam kriteria 0,60-0,799 (kuat) dan terdapat pengaruh signifikan Kompensasi (X3) terhadap kinerja karyawan $(Y)$ dengan nilai rho $(\rho)$ hitung $=0,678$ dalam kriteria 0,600,799 (kuat). Hasil uji t membuktikan bahwa terdapat pengaruh yang signifikan motivasi (X1) terhadap kinerja karyawan (Y) diketahui bahwa nilai t hitung adalah 6,190 dan nilai tersebut menunjukan t hitung lebih besar dari pada $\mathrm{t}$ tabel $(6,190>1,671)$, terdapat pengaruh yang signifikan Pelatihan (X2) terhadap kinerja karyawan (Y) diketahui bahwa nilai t hitung adalah 7,192 dan nilai tersebut menunjukan $t$ hitung lebih besar dari pada $t$ tabel $(7,192>1,671)$ dan terdapat pengaruh yang signifikan Kompensasi (X3) terhadap kinerja karyawan (Y) diketahui bahwa nilai $t$ hitung adalah 7,017 dan nilai tersebut menunjukan t hitung lebih besar dari pada t tabel $(7,017>1,671)$.

\section{ABSTRACT}

This study aims to determine the effect of motivation, training and compensation on employee performance at PT. Wahyu Septyan Bengkulu. The sample in this study were 60 employees of PT. Wahyu Septyan Bengkulu. The data were collected using a questionnaire and the method of analysis used was the rank spearman and the t test.The results of the Spearman rank analysis show that there is a significant influence of motivation (X1) on employee performance $(Y)$ with the value of rho $(\rho)=$ 0.631 in the criteria from 0.60 to 0.799 (strong), there is a significant effect of training (X2) on employee performance $(Y)$ with the value of rho $(\rho)$ count $=0.687$ in the criteria 0.60-0.799 (strong) and there is a significant effect of Compensation (X3) on employee performance $(Y)$ with the value of rho $(\rho)$ count $=0.678$ in the criteria $0.60-0.799$ (strong). The results of the $t$ test prove that there is a significant effect of motivation (X1) on employee 
performance $(Y)$. It is known that the $t$ value is 6,190 and this value shows that $t$ is greater than $t$ table $(6,190>1,671)$, there is a significant effect of training (X2) on employee performance (Y), it is known that the $t$ value is 7.192 and this value shows the $t$ count is greater than the table (7.192> 1.671) and there is a significant effect of compensation (X3) on employee performance $(Y)$. $t$ count is 7,017 and this value shows $t$ count is bigger than table $(7,017>1,671)$..

\section{PENDAHULUAN}

Pada era globalisasi saat ini banyak perusahaan swasta maupun pemerintah berkompetisi dalam dunia bisnis untuk saling menguasai pangsa pasar secara luas, banyak cara ataupun strategi dari segala aspek yang dilakukan perusahaan agar terwujudnya suatu tujuan perusahaan dalam memajukan dan mengembangkan perusahaan demi untuk bisa menguasai pangsa pasar dan mempertahankannya dengan terus melakukan inovasi yang terus menerus seiring kebutuhan pasar yang semakin fluktuatif sesuai perkembengan zaman.

Keberhasilan suatu perusahaan di dalam dunia bisnis tentunya tidak terlepas dari peran aktif Sumber Daya Manusia (SDM) yang Produktif, maka dari itu Sumber Daya Manusia dapat diartikan sebagai aset terbesar perusahaan selain dari materi maupun teknologi yang berkembang saat ini. Sumber Daya Manusia dalam hal ini yaitu Karyawan yang bekerja di dalam suatu perusahaan untuk mewujudkan semua cita-cita atau visi dan misi perusahaan.Agar terciptanya Sumber Daya Manusia yang produktif dibutuhkan Pengelolaan Sumber Daya Manusia yang baik dan efektif sehingga dapat menjadi Sumber Daya Manusia yang memiliki kompetensi atau keahlian yang handal dalam bekerja.

Motivasi merupakan bagian dari cara pengelolaan Sumber Daya Manusia karena motivasi menurut Samsudin (2010 : 281) adalah suatu proses mempengaruhi atau mendorong dari luar terhadap seseorang atau kelompok kerja sehingga mereka mau melaksanakan sesuatu yang telah ditetapkan, maksudnya dengan adanya dorongan dan arahan yang baik terhadap Sumber Daya Manusia dapat meningkatkan semangat atau etos kerja yang tinggi, disamping itu juga agar motivasi dapat tepat sasaran sesuai dengan tujuan dan harapan terkait kinerja, hendaknya perusahaan memberikan pelatihan terhadap Sumber Daya Manusia secara Continue dan ter-Update seiring kebutuhan terhadap suatu pekerjaan yang akan dilakukannya sehingga menghasilkan kinerja yang produktif.

Pelatihan akan memberikan kesempatan bagi Sumber Daya Manusia untuk mengembangkan keahlian dan kemampuan dalam bekerja sehinggadiharapkan dapat memiliki skill, cara berfikir dan perbaikan etika atau sikap sesuai yang dibutuhkan perusahaan, hal ini juga didukung oleh instruksi Presiden No. 15 tahun 1974 yang menyatakan bahwa pelatihan adalah bagian pendidikan yang menyangkut proses belajar untuk memperoleh dan meningkatkan keterampilan di luar sistem pendidikan yang berlaku dalam waktu yang relatif singkat dan dengan metode yang lebih mengutamakan praktek dari pada teori.Ketika motivasi dan pelatihan dilaksanakan dengan baik dan menghasilkan Sumber Daya Manusia yang berpotensial maka diharapkan perusahaan dapat memberikan sikap kepedulian dalam bentuk kompensasi terhadap Sumber Daya Manusia atau Karyawan yang selama ini telah memberikan segenap tenaga dan pemikirannya dalam membantu segala pekerjaan yang ada di perusahaan agar terus tumbuh dan berkembang serta mencapai semua visi dan misi perusahaan.

Kompensasi merupakan salah satu upaya dari cara pengelolaan Sumber daya Manusia dikarenakan sebagai suatu sikap perusahaan dalam mempertahankan Sumber Daya Manusia dengan memberikan profit atau value atas jasa dan loyalitasnya terhadap perusahaan, hal ini sesuai dengan yang dikemukakan oleh Hasibuan (2015:119) yaitu kompensasi merupakan semua pendapatan yang berbentuk uang, barang langsung atau tidak langsung yang diterima karyawan sebagai imbalan atas jasa yang diberikan kepada perusahaan, sistem kompensasi ini memiliki 
dampak terhadap kinerja yang strategis. PT. Wahyu Septyan Bengkulu merupakan badan usaha yang bergerak dibidang jasa outsourching (Penyedia Tenaga Alih Daya), berbagai macam tenaga alih daya yang disalurkan oleh PT. Wahyu Septyan ke perusahaan - perusahaan yang membutuhkan Tenaga Alih Daya seperti office boy, security, driver, cleaning servicedan lain sebagainya.

Semakin besarnya persaingan usaha khususnya dalam bidang jasa outsourchingdan untuk menguasai dunia bisnis tersebutPT. Wahyu Septyanmelalui kegiatan operasionalnya selalu berupaya memberikan pelayanan jasa yang terbaik serta menjalin hubungan erat terhadap client guna terciptanya loyalitas client yang berkesinambungan terhadap PT. Wahyu Septyan Bengkulu. Hal tersebut tentunya perlu peran efektiv karyawan agar tidak terjadinya kendala atau keluhan dari client, salah satu cara agar pelayanan terbaik tetap terjaga yaitu dengan memberikan motivasi, pelatihan dan kompensasi terhadap karyawan agar tumbuhnya semangat kerja dan meningkatkan nilai kinerja karyawan, karena selama ini masih terdapat penurunan kinerja karywan yang disebabkan terlalu santainya karyawan dalam menyelesaikan suatu pekerjaan dan sering membawa masalah pribadi kedalam dunia kerja. Disamping itu juga masih ada karyawan yang melakukan kesalahan dalam menyelesaikan pekerjaan dikarenakan kurangnya pemahaman karyawan terhadap tugas kerja yang diembannya lalu masih ada karyawan yang suka mengeluh dengan banyaknya beban kerja dan tekanan dari atasan.Sehingga kondisi hal seperti ini dapat menurunkan kinerja karyawan.

\section{LANDASAN TEORI}

\section{Pengertian Motivasi}

Salah satu dengan adanya motivasi menjadi dorongan yang ada pada diri manusia baik internal maupun eksternal untuk meningkatkan potensi dalam diri guna memberikan kinerja terbaik untuk perusahaan. Menurut Widodo (2015: 187) motivasi merupakan kekuatan yang ada dalam diri seseorang, yang mendorong perilakunya untuk melakukan tindakan. Besarnya intensitas kekuatan dari dalam diri seseorang untuk melakukan suatu tugas atau mencapai sasaran memperlihatkan sejauh mana tingkat motivasinya, hal ini juga sejalan dengan yang dikemukakan oleh Winardi (2016:6) bahwa motivasi merupakan suatu kekuatan potensial yang ada di dalam diri seorang manusia, yang dapat dikembangkannya sendiri atau dikembangkan oleh sejumlah kekuatan luar yang pada intinya berkisar sekitar imbalan moneter dan imbalan non moneter, yang dapat mempengaruhi hasil kinerjanya secara positif atau negatif.Motivasi juga sebagai suatu gerak yang mengatur perilaku manusia melakukan sesuatu sebagaimana menurut Darmawan (2013: 41) motivasi adalah keadaan jiwa yang mendorong, mengaktifkan atau menggerakan seseorang yang kelak mengarahkan serta menyalurkan perilaku, sikap, dan tindakan yang selalu dikaitkan dengan pencapaian tujuan, baik tujuan pribadi masing-masing anggota. Motivasi didefinisikan tiga komponen utamanya yaitu kebutuhan, dorongan dan tujuan.

\section{Pengertian Pelatihan}

Salah satu upaya untuk memberdayakan keterampilan dasar tersebut yaitu melaksanakan serangkaian proses belajar yang bekelanjutan bagi seluruh karyawan melalui pelatihan. Menurut Widodo (2015:82), pelatihan merupakan serangkaian aktivitas individu dalam meningkatkan keahlian dan pengetahuan secara sistematis sehingga mampu memiliki kinerja yang profesional di bidangnya. Sedangkan menurut Rivai dan Sagala (2011:212), pelatihan adalah proses secara sistematis mengubah tingkah laku pegawai untuk mencapai tujuan organisasi.

Dari beberapa pendapat para ahli di atas, dapat disimpulkan bahwa pelatihan adalah suatu kegiatan pemberian pendidikan dan pengetahuan dalam jangka waktu yang relatif singkat menggunakan metode yang mengutamakan praktek daripada teori agar karyawan semakin terampil, mampu melaksanakan tanggung jawabnya dengan baik, dan sesuai standar. 


\section{Pengertian Kompensasi}

Menurut Hasibuan (2015:118) Kompensasi adalah semua pendapatan yang berbentuk uang, barang langsung atau tidak langsung yang diterima karyawan sebagai imbalan atas jasa yang diberikan kepada perusahaan. Menurut Handoko (2017:155) Kompensasi adalah segala sesuatu yang diterima para karyawan sebagai balas jasa untuk kerja mereka. Program- program kompensasi juga penting bagi perusahaan, karena mencermintakan upaya organisasi untuk mempertahankan sumber daya manusia.

\section{METODE PENELITIAN}

Penelitian yang dilakukan ini merupakan jenis penelitian kuantitatif dan berasifat asosiatif kausal. Penelitian kuantitaif salah satu jenis penelitian yang konkrit, obyektif, terukur, rasional dan sistematis. menurut Sugiyono (2013:13), penelitian kuantitatif merupakan penelitian yang berlandaskan pada filsafat positivisme, digunakan untuk meneliti pada populasi atau sampel tertentu, teknik pengambilan sampel pada umumnya dilakukan secara random, pengumpulan data menggunakan instrumen penelitian, analisis data bersifat kuantitatif/statistik dengan tujuan untuk menguji hipotesis yang telah ditetapkan.Menurut Sugiyono (2013:55), penelitian asosiatif kausal adalah penelitian yang bertujuan untuk mengetahui hubungan antara dua variabel atau lebih. Dengan penelitian ini maka akan dapat dibangun suatu teori yang berfungsi untuk menjelaskan, meramalkan dan mengontrol suatu gejala. Hubungan kausal merupakan hubungan yang sifatnya sebab-akibat, salah satu variabel (independen) mempengaruhi variabel yang lain (dependen). Penelitian asosiatif menggunakan teknik analisis kuantitatif atau statistik. Sehingga dalam penelitian ini diharapkan dapat menginterprestasikan dengan jelas dan secara terukur pengaruh motivasi, pelatihan dan kompensasi terhadap kinerja karyawan PT. Wahyu Septyan di Kota Bengkulu.

\section{HASIL DAN PEMBAHASAN}

Hasil dan Pembahasan

Berdasarkan hasil perhitungan korelasi rank spearman dan pengujian hipotesis diperoleh hasil sebagaimana pada tabel berikut ini:

Tabel 1. Rekap hasil penelitian dengan perhitungan korelasi dan uji hipotesis antara X1 dengan Y

\begin{tabular}{|c|c|c|c|c|c|}
\hline Variabel & $\begin{array}{l}\text { Korelasi Rank } \\
\text { Spearman (x) }\end{array}$ & Kriteria & t hitung & t tabel & Kriteria \\
\hline $\begin{array}{l}\text { Motivasi (X1) dan Kinerja } \\
\text { Karyawan (Y) }\end{array}$ & 0,631 & Kuat & 6,190 & 1,671 & Signifikan \\
\hline
\end{tabular}

Sumber: Hasil penelitian, Diolah 2021

Dalam analisis korelasi rank spearman pada pengaruh motivasi, terhadap kinerja karyawan pada PT. Wahyu Septyan Bengkulu diperoleh nilai rho $(p)$ 0,631 dengan kriteria kuat karena hasil korelasinya terletak pada interval koefesien antara 0,60 - 0,799 sedangkan dari hasil uji hipotesis hubungan antara motivasi dengan kinerja karyawan pada PT. Wahyu Septyan Bengkulu adalah 6,190 dan dapat disimpulkan bahwa hipotesis yang diajukan dalam penelitian ini dapat dibuktikan bahwa motivasi (X1) mempunyai pengaruh signifikan terhadap kinerja karyawan pada PT. Wahyu Septyan Bengkulu karena nilai t hitung lebih besar dari t tabel $(6,190>1,671)$.Dalam pernyataan tersebut menerengkan bahwa motivasi sebagai faktor yang dapat mempengaruhi karyawan dalam peningkatan kinerjanya, hal ini sejalan dengan hasil penelitian terdahulu dari Eris Pebrian Nanda (2019) diketahui variabel Motivasi berpengaruh terhadap Kinerja dengan hasil uji t 1,662 (sig.0,01<0,05). Dalam hal ini pendapat Winardi (2016:6) bahwa motivasi merupakan suatu kekuatan 
potensial yang ada di dalam diri seorang manusia, yang dapat dikembangkannya sendiri atau dikembangkan oleh sejumlah kekuatan luar yang pada intinya berkisar sekitar imbalan moneter dan imbalan non moneter, yang dapat mempengaruhi hasil kinerjanya secara positif atau negatif.

Tabel 2. Rekap hasil penelitian dengan perhitungan korelasi dan uji hipotesis antara X2 dengan Y

\begin{tabular}{|l|l|l|l|l|l|l|}
\hline \multicolumn{2}{|c|}{ Variabel } & $\begin{array}{l}\text { Korelasi Rank } \\
\text { Spearman ( }\end{array}$ & Kriteria & t hitung & t tabel & Kriteria \\
\hline $\begin{array}{l}\text { Pelatihan (X2) dan Kinerja } \\
\text { Karyawan }(\mathrm{Y})\end{array}$ & 0,687 & Kuat & 7,192 & 1,671 & Signifikan \\
\hline
\end{tabular}

Sumber: Hasil penelitian, Diolah 2021

Dalam analisis korelasi rank spearman pada pengaruh pelatihan, terhadap kinerja karyawan pada PT. Wahyu Septyan Bengkulu diperoleh nilai rho $(p)$ 0,687 dengan kriteria kuat karena hasil korelasinya terletak pada interval koefesien antara 0,60 - 0,799 sedangkan dari hasil uji hipotesis hubungan antara motivasi dengan kinerja karyawan pada PT. Wahyu Septyan Bengkulu adalah 7,192 dan dapat disimpulkan bahwa hipotesis yang diajukan dalam penelitian ini dapat dibuktikan bahwa pelatihan (X2) mempunyai pengaruh signifikan terhadap kinerja karyawan pada PT. Wahyu Septyan Bengkulu karena nilai t hitung lebih besar dari t tabel $(7,192>1,671)$. Dalam pernyataan tersebut menerangkan bahawa dengan adanya pelatihan dapat meningkatkan keahlian atau pengetahuan karyawan sehingga mempengaruhi peningkatan kinerjanya, hal ini sejalan dengan pendapat Widodo (2015:82) yaitu pelatihan merupakan serangkaian aktivitas individu dalam meningkatkan keahlian dan pengetahuan secara sistematis sehingga mampu memiliki kinerja yang profesional di bidangnya.

Tabel 3. Rekap hasil penelitian dengan perhitungan korelasi dan uji hipotesis antara X3 dengan Y

\begin{tabular}{|l|l|l|l|l|l|}
\hline \multicolumn{1}{|c|}{ Variabel } & $\begin{array}{c}\text { Korelasi } \\
\text { Rank Spearman (r) }\end{array}$ & Kriteria & t hitung & t tabel & Kriteria \\
\hline $\begin{array}{l}\text { Kompensasi(X3) dan Kinerja } \\
\text { Karyawan }(\mathrm{Y})\end{array}$ & 0,678 & Kuat & 7,017 & 1,671 & Signifikan \\
\hline
\end{tabular}

Sumber : Hasil penelitian, Diolah 2021

Dalam analisis korelasi rank spearman pada pengaruh kompensasi terhadap kinerja karyawan pada PT. Wahyu Septyan Bengkulu diperoleh nilai rho $(p)$ 0,678dengan kriteria kuat karena hasil korelasinya terletak pada interval koefesien antara 0,60 - 0,799 sedangkan dari hasil uji hipotesis hubungan antara motivasi dengan kinerja karyawan pada PT. Wahyu Septyan Bengkulu adalah 7,017 dan dapat disimpulkan bahwa hipotesis yang diajukan dalam penelitian ini dapat dibuktikan bahwa kompensasi (X3) mempunyai pengaruh signifikan terhadap kinerja karyawan pada PT. Wahyu Septyan Bengkulu karena nilai t hitung lebih besar dari t tabel $(7,017>1,671)$, hal ini sejalan dengan hasil penelitian terdahulu dari Tati Hartati (2020) yang menyatakan variabel kompensasi berpengaruh terhadap kinerja karyawan dengan hasil uji simultan 0,90 (90\%) dan dinyatakan signifikan. Dalam pernyataan terebut menerangkan bahwa kompensasi menurut Hasibuan (2015:118) yaitu semua pendapatan yang berbentuk uang, barang langsung atau tidak langsung yang diterima karyawan sebagai imbalan atas jasa yang diberikan kepada perusahaan. Sehingga karyawan dapat merasa semangat dalam meningkatkan kinerjanya.

\section{KESIMPULAN DAN SARAN}

Kesimpulan

1. Nilai koefesien korelasi spearman rank terhadap variabel motivasi (X1) dengan variabel kinerja karyawan $(Y)$, diketahui nilai rho $(\rho)$ hitung $=0,631$ artinya ada pengaruh variabel motivasi 
terhadap kinerja karywan pada PT. Wahyu Septyan Bengkulu dengan kriteria kuat, karena nilai korelasi berada pada 0,60-0,799.

2. Nilai koefesien korelasi spearman rank terhadap variabel pelatihan (X2) dengan variabel kinerja karyawan $(Y)$, diketahui nilai rho $(\rho)$ hitung $=0,687$ artinya ada pengaruh variabel pelatihan terhadap kinerja karywan pada PT. Wahyu Septyan Bengkulu dengan kriteria kuat, karena nilai korelasi berada pada 0,60-0,799.

3. Nilai koefesien korelasi spearman rank terhadap variabel kompensasi (X3) dengan variabel kinerja karyawan $(\mathrm{Y})$, diketahui nilai rho $(\rho)$ hitung $=0,678$ artinya ada pengaruh variabel kompensasi terhadap kinerja karywan pada PT. Wahyu Septyan Bengkulu dengan kriteria kuat, karena nilai korelasi berada pada 0,60-0,799

4. Uji hipotesis antara motivasi (X1) dengan kinerja karyawan (Y) pada PT. Wahyu Septyan Bengkulu diketahui bahwa nilai t hitung adalah 6,190 dan nilai tersebut menunjukan t hitung lebih besar dari pada t tabel $(6,190>1,671)$ maka hipotesis yang diajukan dalam penelitian ini terbukti bahwa motivasi mempunyai pengaruh signifikan terhadapkinerja karyawan pada PT. Wahyu Septyan Bengkulu.

5. Uji hipotesis antara pelatihan (X2) dengan kinerja karyawan (Y) pada PT. Wahyu Septyan Bengkulu diketahui bahwa nilai t hitung adalah 7,192 dan nilai tersebut menunjukan t hitung lebih besar dari pada t tabel $(7,192>1,671)$ maka hipotesis yang diajukan dalam penelitian ini terbukti bahwa pelatihan mempunyai pengaruh signifikan terhadap kinerja karyawan pada PT. Wahyu Septyan Bengkulu.

6. Uji hipotesis antara kompensasi (X3) dengan kinerja karyawan (Y) pada PT. Wahyu Septyan Bengkulu diketahui bahwa nilai t hitung adalah 7,017 dan nilai tersebut menunjukan t hitung lebih besar dari pada t tabel $(7,017>1,671)$ maka hipotesis yang diajukan dalam penelitian ini terbukti bahwa kompensasi mempunyai pengaruh signifikan terhadap kinerja karyawan pada PT. Wahyu Septyan Bengkulu.

\section{Saran}

1. PT. Wahyu Septyan Bengkulu sejauh ini dalam memberikan motivasi terhadap karyawannya sudah dalam kategori baik, namun hendaknyaperusahaan jangan pernah berhenti ataupun lemah dalam memberikan motivasi, karnanya motivasi akan menjadi pedoman perbaikan atau kewaspadaan karyawan dalam melakukan pekerjaannya, sehingga peningkatan kinerja karyawan akan tercipta lebih baik dan tujuan serta visi, misi perusahaan dapat terwujud dengan optimal.

2. PT. Wahyu Septyan Bengkulu hendaknya selalu terus menurus dalam memberikan pelatihan minimal 1 tahun sekali yang berorientai pada teknologi ter-update agar karyawan memiliki kemampuan dan keahlian yang menyesuaikan kebutuhan dunia kerja.

3. PT. Wahyu Septyan Bengkulu harus selalu memberikan hak-hak karyawan secara teratur baik dalam bentuk materi maupun non materi agar karyawan lebih bersemangat dalam meningkatkan kinerjanya untuk perusahaan.

\section{DAFTAR PUSTAKA}

A.A. Anwar Prabu Mangkunegara. 2016.Manajemen Sumber Daya Manusia Perusahaan. Bandung: PT. Remaja Rosdakarya.

Arikunto, Suharsimi. 2015. Dasar-dasar Evaluasi Pendidikan. Jakarta: Bumi Aksara

Darmawan, D. H. (2013).Prinsip-prinsip Perilaku Organisasi. Surabaya: Pena Semesta.

Djarwanto dan Pangestu Subagyo. 2016. Statistik Induktif. Yogyakarta. BPFE.

Ghozali, Imam. 2018. Aplikasi Analisis Multivariate dengan Program IBM SPSS 25. Semarang, Badan Penerbit Universitas Diponegoro. 
Handoko. 2017. Manajemen Sumber Daya Manusia. Edisi Revisi. Jakarta. Bumi Aksara. Metodelogi Penelitian Untuk Skripsi dan Tesis Bisnis. Jakarta: P Gramedia Pustaka.

Hartati, T., 2020. Analysis of Influence of Motivation, Competence, Compensation toward Performance of Employee. Budapest International Research and Critics Institute (BIRCIJournal): Humanities and Social Sciences, 3(2), pp.1031-1038.

Hasibuan, Malayu S,P. 2015. Manajemen Sumber Daya Manuia. Jakarta. PT.Bumi Aksara.

Herwin Susanto, Karona Cahya Susena, \& Abdul Rahman. (2020). The Relationship Of Leadership Style, Competence And Compensation To Employee Performance In Seluma Regional Secretariat. Jurnal Ekonomi, Manajemen, Akuntansi Dan Keuangan, 1(2), 72-82.

Intruksi Presiden Nomor 15 tahun 1974 Tentang Pelatihan.

Irwanto, T. and Melinda, T.F., 2015. Pengaruh Disiplin dan Motivasi dan Kinerja Pegawai Dinas Peternakan dan Kesehatan Hewan Provinsi Bengkulu. EKOMBIS REVIEW: Jurnal IImiah Ekonomi dan Bisnis, 3(2).

Kadarisman, M. 2012. Manajemen Pengembangan Sumber Daya Manusia. Jakarta: Rajawali Pers.

Moeheriono. 2012. Pengukuran Kinerja Berbasis Kompetensi. Jakarta: Raja Grafindo Persada.

Nawawi, 2011, Manajemen Sumber Daya Manusia: Untuk Bisnis Yang Kompetitif. Gajah Mada University Press. Yogyakarta.

Rivai, Veithzal dan Basri. 2016. Performance Appraisal: Sistem Yang Tepat Untuk Menilai Kinerja Karyawan Dan Meningkatkan Daya Saing Perusahaan. Jakarta.Grafindo.

Rivai,Veithzal dan Sagala, Ella Jauvani.2011. Manajemen Sumber Daya Manusia untuk Perusahaan dari Teori ke Praktik. Jakarta. PT Raja Grafindo.

Sadili Samsudin. 2010.Manajemen Sumber Daya Manusia. Bandung : CV. Pustaka Setia.

Subekhi. Akhmad, Jauhar Mohammad. 2012. Pengantar Manajemen Sumber Daya Manusia. Prestasi Pustaka. Jakarta.

Sugiyono. 2013.Metode Penelitian Pendidikan Pendekatan Kuantitatif, Kualitatif dan R\&D. Bandung: Alfabeta

Widodo, S. E. (2015). Manajemen Pengembangan Sumber Daya Manusia, Yogyakarta: Pusaka Pelajar.

Winardi. 2016. Kepemimpinan dalam Manajemen. Jakarta: PT. Rineka Cipta.

Yadi. 2012. Pengaruh Motivasi untuk Meningkatkan Kinerja Karyawan pada CV Dharma Utama (Duta Paint) Kota Batu. Skripsi tidak dipublikasikan. 